\title{
Alendronate Lowers Cholesterol Synthesis in the Central Nervous System of Rats - a Preliminary Study
}

\author{
L. CIBIČKOVÁ ${ }^{1}$, R. HYŠPLER ${ }^{3}$, N. CIBIČEK ${ }^{2}$, E. ČERMÁKOVÁ ${ }^{4}$, V. PALIČKA ${ }^{2}$ \\ ${ }^{1}$ Second Department of Medicine, ${ }^{2}$ Institute of Clinical Biochemistry and Diagnostics, ${ }^{3}$ Department \\ of Gerontology and Metabolism, Research Laboratory, ${ }^{4}$ Computer Technology Center, Charles \\ University in Prague, Medical Faculty in Hradec Králové and University Hospital, Hradec Králové, \\ Czech Republic
}

Received August 22, 2007

Accepted May 20, 2008

On-line July 18, 2008

\begin{abstract}
Summary
Nitrogen-containing bisphosphonates were found to inhibit farnesyl diphosphate synthase - an essential enzyme in the cholesterol biosynthesis pathway, but their effect on cholesterol synthesis per se in the central nervous system (CNS) remains unknown. The aim of the present study was to examine possible influence of a representative agent alendronate on cholesterol synthesis rates in selected parts of rat CNS and on plasma cholesterol level. Two groups of rats were orally administered either alendronate ( $3 \mathrm{mg} / \mathrm{kg} \mathrm{b.w.)}$ or vehicle for 9 days. At the end of experiment, brain (basal ganglia, frontal cortex and hippocampus) and spinal cord were isolated and cholesterol synthesis was determined using the technique of deuterium incorporation from deuterated water. In the alendronate group significant reductions of cholesterol synthesis rates were detected in frontal cortex, hippocampus and spinal cord $(p<0.001)$. However, the experimental treatment did not produce a significant alteration in the levels of plasma cholesterol. In conclusion, this study brings the first experimental evidence of the inhibition of cholesterol biosynthesis with alendronate in central nervous system.
\end{abstract}

\section{Key words}

Brain cholesterol synthesis • Bisphosphonates • Alendronate • Deuterium oxide

\section{Corresponding author}

L'. Cibičková, Second Department of Medicine, University Hospital, Sokolská 581, 50005 Hradec Králové, Czech Republic. Fax: +420 495514 022. E-mail: cibickova@seznam.cz
Cholesterol has been widely discussed as a molecule participating in the pathophysiology of neurodegenerative diseases. The putative role of cholesterol in Alzheimer's disease (AD) is supported by reports indicating a decreased risk of this condition by cholesterol-lowering drugs - statins (Rockwood et al. 2002, Zandi et al. 2005). Statins block a rate-limiting step in the cholesterol biosynthesis cascade via 3-hydroxymethyl-glutaryl-coenzyme A (HMG-CoA) reductase inhibition. As a consequence, the production of amyloid$\beta$ (the characteristic AD protein) may be diminished (Fassbender et al. 2002, Simons et al. 1998).

The latest and most potent bisphosphonates, nitrogen-containing bisphosphonates (N-BPs, e.g. alendronate) were found to be potent inhibitors of cholesterol biosynthesis from mevalonate (Amin et al. 1992). In the corresponding pathway, the enzyme farnesyl diphosphate synthase (isopentenyl transferase) has recently been identified as the molecular target of $\mathrm{N}$ BPs (Rezka and Rodan 2004). Although the use of bisphosphonates has been indicated primarily and principally for treatment and prevention of bone health disturbances such as osteoporosis, the similarity with statins regarding the mechanism of action suggests an analogy in the alternative use of N-BPs.

We hypothesized that alendronate lowers cholesterol biosynthesis in the central nervous system (CNS) in a similar way to statins. Hence, the aim of the 
Table 1: FSR (fraction synthesis rates) of cholesterol in various parts of the central nervous system

\begin{tabular}{lllll}
\hline & Hippocampus & Basal ganglia & Frontal lobe & Spinal cord \\
\hline Controls & $0.048 \pm 0.0106$ & $0.031 \pm 0.0075$ & $0.056 \pm 0.0087$ & $0.031 \pm 0.0087$ \\
Alendronate & $0.035 \pm 0.0076^{* * *}$ & $0.030 \pm 0.0072$ & $0.038 \pm 0.0077^{* * *}$ & $0.014 \pm 0.0084^{* * *}$ \\
\hline
\end{tabular}

Results are expressed as mean \pm S.D., $* * * \mathrm{p}<0.001$ vs. controls.

present study was to determine possible modifications in plasma cholesterol levels and cholesterol synthesis rates in selected parts of rat brain and spinal chord after exposure to alendronate.

We have used adult male rats of Wistar strain (body weight $240 \mathrm{~g}$ at delivery). The rats had free access to standard laboratory rat chow pellets except for 16-18h before and $1 \mathrm{~h}$ after experiment, when they were fasted. The second day rats received a loading dose of deuterated water $\left(35 \mathrm{ml} / \mathrm{kg} 99 \%\right.$ enriched $\left.{ }^{2} \mathrm{H}_{2} \mathrm{O}\right)$ and then had free access to drinking water enriched $10 \%$ with ${ }^{2} \mathrm{H}_{2} \mathrm{O}$ (Diraison et al. 1996). Drugs were administered by gavage via a metallic gastric probe every day between 9:00 and 11:00 a.m. for nine days. For individual dose adjustment, animals were weighed before each application. All animals received care in accordance with the guidelines set by the institutional Animal Use and Care Committee of the Charles University in Prague, Czech Republic. Animals were randomly divided into two groups, eight rats in each. The first (sham) group received vehicle only (water), whereas the second group was administered alendronate $(3 \mathrm{mg} / \mathrm{kg}$ b.w., MSD, Netherlands). On the last (ninth) day of experiment, one hour after drug application, animals were put under pentobarbital anesthesia (50 mg/kg i.p.) and were sacrificed by exsanguination from abdominal aorta. Their brain and spinal chord were immediately exteriorized and basal ganglia, frontal lobe and hippocampus were isolated.

Individual parts of brain were homogenized using KIA T10 basic, Ultra-Turrax homogenizer (IKAWerke, Germany) and extracted according the method of Bilgh and Dyer (1959). Briefly, tissue samples were mixed with methanol:water solution (2:0.8) and extracted to chloroform using Stuart rotator (Barloworld Scientific, Stone, UK). The chloroform layer was separated, evaporated to dryness and cholesterol was derivatized using acetylchloride solution in chloroform (1:5) for one hour (Liebisch et al. 2006). The mixture was evaporated under nitrogen and residue containing cholesterol acetate was dissolved in $\mathrm{n}$-hexane for analysis. Analysis was performed on GC-MS system (Perkin-Elmer, Norwalk, USA) operating in electron ionization mode. The injector temperature was set to $300{ }^{\circ} \mathrm{C}$, slit ratio $1: 10$, oven $320^{\circ} \mathrm{C}$ isothermally, ionization source $280{ }^{\circ} \mathrm{C}$. The ions $\mathrm{m} / \mathrm{z}$ 368.6, 369.6 and 370.6 were recorded, isotope excess and fractional synthesis rate were calculated according to Diraison et al. (1997). The deuterium oxide enrichment was determined from plasma as described previously (Yang et al. 1998) using hydrogen atom exchange between water and acetone in alkaline solution. For statistical evaluation, descriptive measures, normality tests followed by ANOVA with Fisher's LSD post hoc Multiple-Comparison Test (brain data) and MannWhitney test (plasma data), were applied. The employed programs were NCSS 2004, Statistica and GraphPad InStat.

Treatment with given dose of alendronate for nine days did not produce any change in plasma cholesterol $(1.37,1.02-2.86$ for alendronate vs. 1.24, $0.98-2.50$ for controls; $p=0.44$, results are expressed as median, minimum-maximum). However, the administered dosage significantly $(\mathrm{p}<0.001)$ decreased the rate of cholesterol synthesis in three distinct parts of the CNS (hippocampus, frontal lobe and spinal cord, for details see Table 1).

The specified areas of brain were selected respecting their relevance in $\mathrm{AD}$ pathophysiology hippocampus, basal ganglia and frontal lobe are the most severely affected structures by degeneration of cholinergic system.

Very limited data are available concerning the potency of bisphosphonates to inhibit cholesterol biosynthesis. In humans, Canigga et al. (1974) were the first to demonstrate the ability of supratherapeutic doses of etidronate to lower serum cholesterol and total lipid levels. These findings were supported by Montagnani et al. (2003) who documented an induction of a weak decrease in total cholesterol and cholesterol-shift from the low density lipoprotein to high density lipoprotein fraction in patients with Paget's bone disease by ninemonth treatment with pamidronate (three times $60 \mathrm{mg}$ 
i.v.). On the other hand, three week-administration of alendronate ( $3 \mathrm{mg} / \mathrm{kg}$ p.o. daily) to ovariectomized rats did not elicit significant effect on plasma cholesterol levels (Frolik et al. 1996). Our present results agree with the latter findings and indicate that either the dosage used ( $3 \mathrm{mg} / \mathrm{kg}$ p.o. daily for nine days) is either insufficient to produce significant effects on plasma cholesterol levels or the ability of alendronate to lower plasma cholesterol in rats is challenged.

With regard to CNS, the finding of lowered cholesterol biosynthesis due to alendronate treatment is unique. In this respect alendronate (a BBB penetrating drug) mimics the action of lipophilic statins (as demonstrated on by the decrease of lathosterol Lutjohann et al. 2004, Simons et al. 2005, Hoglund et al. 2005) and analogically suggests a possible connection with cholinergic neurotransmission. Firstly, the levels of total brain cholesterol were shown to correlate positively with the amount of amyloid beta $(\mathrm{A} \beta$ ) (Refolo et al. 2000), a peptide known for its ability to increase the activity of acetylcholinesterase (AChE) in vitro (Hu et al. 2003). Secondly, alendronate also suppresses AChE activity in frontal cortex (the site of the highest $A \beta$ accumulation) as has recently been demonstrated in our previous study (Cibičková et al. 2007). Finally, build-up of $A \beta$ peptide is associated with a reduction of cholinergic transmission, which is characteristic for Alzheimer disease. Since other cholesterol-lowering drugs (statins) play a putative preventive role in $\mathrm{AD}$, these facts create some space for speculation about future feasibility of studying N-BPs in terms of AD prevention and/or treatment. However, the possible impacts of $\mathrm{N}$ $\mathrm{BPs}$ on $\mathrm{A} \beta$ generation and $\mathrm{AD}$ epidemiology remain to be determined.

This experimental study brings the first evidence of the inhibitory effect of N-BPs (alendronate) on cholesterol biosynthesis rates in different parts of rat central nervous system. Clinical significance of the described effects of these widely used agents on brain cholesterol synthesis should be resolved in further experiments and human studies.

\section{Conflict of Interest}

There is no conflict of interest.

\section{Acknowledgements}

This work was supported by research project MZO 00179906 and by an internal grant of Medical Faculty in Hradec Králové, Charles University in Prague.

\section{References}

AMIN D, CONELl SA, GUSTAFSON SK, NEEDLE SJ, ULLRICH JW, BILDER GE, PERONE MH: Bisphosphonates used for the treatment of bone disorders inhibit squalene synthase and cholesterol biosynthesis. J Lipid Res 33: 1657-1663, 1992.

BLIGH EG, DYER WJ: A rapid method of total lipid extraction and purification. Can J Biochem Physiol 37: 911-917, 1959.

CANIGGA A, GENNARI C, PICCI M: Disphosphonate (etidronate) lowers cholesterol and total lipid levels in the blood of humans. Bioll Soc Ital Biol Sper 50: 1416-1422, 1974.

CIBIČKOVÁ L, PALIČKA V, CIBIČEK N, ČERMÁKOVÁ E, MIČUDA S, BARTOŠOVÁ L, JUN D: Differential effects of statins and alendronate on cholinesterases in serum and brain of rats. Physiol Res 56: 765-770, 2007.

DIRAISON F, PACHIAUDI C, BEYOT M: In vivo measurement of plasma cholesterol and fatty acid synthesis with deuterated water: determination of the average number of deuterium atoms incorporated. Metabolism 45: 817 $821,1996$.

DIRAISON F, PACHIAUDI C, BEYLOT M: Measuring lipogenesis and cholesterol synthesis in humans with deuterated water: use of simple gas chromatographic/mass spectrometric techniques. J Mass Spectrom 32: 81$86,1997$.

FASSBENDER K, STROICK M, BERTSCH T, RAGOSCHKE A, KUEHL S, WALTER S, WALTER J, BRECHTEL K, MUELHAUSER R, VON BERGMANN K, LUTJOHANN D: Effects of statins on human cerebral cholesterol metabolism and secretion of Alzheimer amyloid peptide. Neurology 59: 1257-1258, 2002.

FROLIK CA, BRYANT HU, BLACK EC, MAGEE DE, CHANDRASEKHAR S: Time-dependent changes in biochemical bole markers and serum cholesterol in ovariectomized rats: effects of raloxifene $\mathrm{HCl}$, tamoxifen, estrogen and alendronate. Bone 18: 621-627, 1996. 
HOGLUND K, THELEN KM, SYVERSEN S, SJOGREN M, VON BERGMAN K, WALLIN A, VANMECHELEN E, VANDERSTICHELE H, LUTJOHANN D, BLENNOW K: The effect of simvastatin treatment on the amyloid precursor protein and brain cholesterol metabolism in patients with Alzheimer's disease. Dement Geriatr Cogn Disord 9: 256-265, 2005.

HU W, GRAY NW, BRIMIJOIN S: Amyloid-beta increases acetylcholinesterase expression in neuroblastoma cells by reducing enzyme degradation. $J$ Neurochem 86: 470-478, 2003.

LIEBISCH G, BINDER M, SCHIFFERER R, LANGMANN T, SCHULZ B, SCHMITZ G: High throughput quantification of cholesterol and cholesteryl ester by electrospray ionization tandem mass spectrometry (ESIMS/MS). Biochim Biophys Acta 1761: 121-128, 2006.

LUTJOHANN D, STROICK M, BERTSCH T, KUHL S, LINDENTHAL B, THELEN K, ANDERSSON U, BJORKHEM BERGMANN KV K, FASSBENDER K: High doses of simvastatin, pravastatin, and cholesterol reduce brain cholesterol synthesis in guinea pigs. Steroids 69: 431-438, 2004.

MONTAGNANI A, GONNELLI S, CEPOLLARO C, CAMPAGNA MS, FRANCI MB, PACINI S, GENNARI C: Changes in serum HDL and LDL cholesterol in patients with Paget's bone disease treated with pamidronate. Bone 32: 15-19, 2003.

REFOLO LM, MALESTER B, LAFRANCOIS J, BRYANT-THOMAS T, WANG R, TINT GS, SAMBAMURTI K, DUFF K, PAPPOLLA MA: Hypercholesterolemia accelerates the Alzheimer's amyloid pathology in a transgenic mouse model. Neurobiol Dis 7: 321-331, 2000.

REZKA AA, RODAN GA: Nitrogen-containing bisphosphonate mechanism of action. Mini Rev Med Chem 4: 711-719, 2004.

ROCKWOOD K, KIRKLAND S, HOGAN DB, MACKNIGHT C, MERRY H, VERREAULT R, WOLFSON C MCDOWELL I: Use of lipid-lowering agents, indication bias, and the risk of dementia in community-dwelling elderly people. Arch Neurol 59: 223-227, 2002.

SIMONS S, KELLER P, DE STROOPER B, BEYREUTHER K, DOTTI CG, SIMONS K: Cholesterol depletion inhibits the generation of beta-amyloid in hippocampal neurons. Proc Natl Acad Sci USA 95: 6460-6464, 1998.

SIMONS M, SCHWARZER F, LUTJOHANN D, VON BERGMANN K, BEYREUTHER K, DICHGANZ J, WORMSTALL H, HARTMANN T, SCHULZ JB: Treatment with simvastatin in normocholesterolemic patients with Alzheimer's disease: a 26-week randomized, placebo-controlled, double-blind trial. Ann Neurol 52: 346-350, 2002.

YANG E, DIRAISON F, BEYLOT M, BRUNENGRABER DZ, SAMOLS MA, ANDERSON VE, BRUNENGRABER H: Assay of low deuterium enrichment of water by isotropic exchange with [U- ${ }^{13} \mathrm{C}_{3}$ ] acetone and gas chromatography-mass spectrometry. Anal Biochem 258: 315-32, 1998.

YLITALO R: Bisphosphonates and atherosclerosis. Gen Pharmacol 35: 287-296, 2002.

ZANDI PP, SPARKS DL, KHACHATURIAN AS, TSCHANZ J, NORTON M, STEINBERG M, WELSH-BOHMER KA, BREITNER JC: Do statins reduce risk of incident dementia and Alzheimer disease? The Cache cohort study. Arch Gen Psychiatry 62: 217-224, 2005. 